\title{
Restoring Bottom-Up Management within Village's Cell: A Village Glory
}

\author{
Juhadi ${ }^{1, *}$ Edy Trihatmoko ${ }^{2,}$ Elok Surya Pratiwii ${ }^{3}$ Makin Basuki, Singgih Supriyanto ${ }^{5}$ \\ ${ }^{1,2,3}$ Department of Geography, Universitas Negeri Semarang, Semarang \\ ${ }^{4}$ Makindo, Bekasi Timur \\ ${ }^{5}$ Deputy of IT Development and Business Technology Innovation. Village Resilience Institute of Republic of Indonesia, \\ Jakarta \\ *Corresponding author.Email: juhadigeo@mail.unnes.ac.id
}

\begin{abstract}
The village, as the smallest administrative boundary in state governance, is a crucial aspect that requires considerable attention. The urgency in line with President Joko Widodo's Nawacita in "Building Indonesia from the Edge." However, village development and management are currently still being managed by mostly using top-down management. Not infrequently the plot of land as the cell or the smallest village unit is untouched by the government. With this top-down management, it puts the village community only as objects, not as subjects. On the other hand, the community itself knows the capabilities and potential of their village even for its single cell. The concept of bottom-up management is considered the most appropriate to be implemented. The management concept is then applied using the Penta helix approach that is formulated in this study, namely the involvement of academics, government, communities, industry, and technology. Technology investment in this study is the latest technology with highest precision, real-time, easy, and lightweight, transforming from 15 gigabytes UAV data into less than 3 megabytes data and application. The results of a joint analysis of the Geospatial Information Agency (BIG) concluded that village management technology in this study would be the first technology in managing databases to village cells, with the query system and the advantages mentioned.
\end{abstract}

Keywords: Bottom-up management, penta helix approach, village management.

\section{INTRODUCTION}

Indonesia is one of the largest archipelago countries in the world. Indonesia's nine presidential agenda summarized on Nawacita concept that focus on "Building Indonesia from the periphery" is a breakthrough that can be said to be suitable for the vast territory of the archipelago. In addition, the outskirts of Indonesia are directly adjacent to several neighboring countries. One implementation of this vision is allocating the annual funds for village directly from the central government. The granting of funds is actually good in supporting the village development, but most of villages are still stuttering in managing it because they do not have adequate data. The availability of this data is also important as a basis for village development planning. As a simple question is "how to manage a village to achieve a high level of welfare?" To answer this, the village requested a complete and accurate database.
Regulatory products and operational policies from the central government cannot be implemented at the village level optimally. An example is Regulation of the Head of Government Goods/Services Procurement Policy (LKPP) No. 22 of 2015 on the Procedures for procurement of goods and services in villages [1]. This condition is considered still biased, because the database is not optimal and tends to be in the form of static data especially for updating in realtime from the village, to the smallest cell in the village. The database that has been used is the village potential data which is updated every three to four years. Moreover, not everyone, especially villagers, can access and understand it. This is because the data are less interactive and not easily accessible for the whole community (Figure 1-3). Another fact that is encountered is that despite the high literacy rate of Indonesian society with $98 \%$ achievements in 2018 [2] however, societies that are accustomed to not being independent in managing village data become more difficult when faced with rigid data. Villagers will tend to be apathetic. 


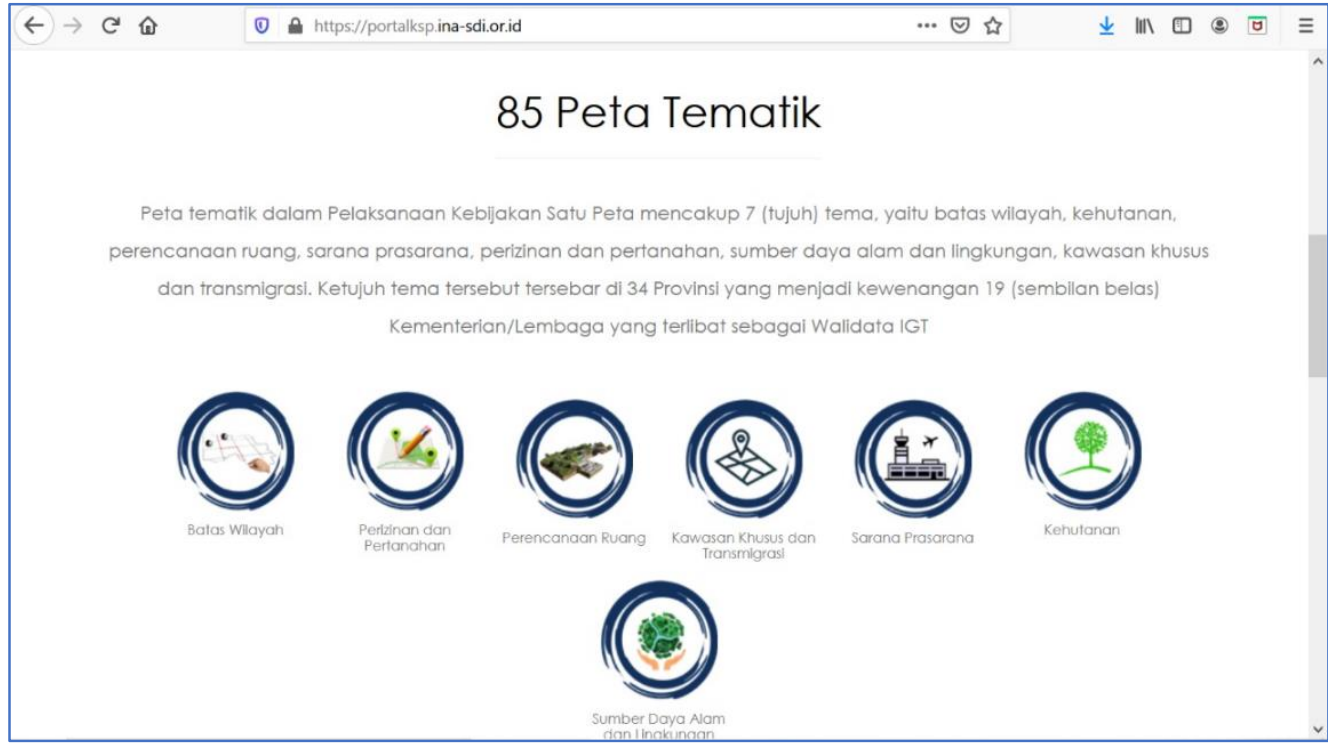

Figure 1. Examples of data provision by the central government [3]

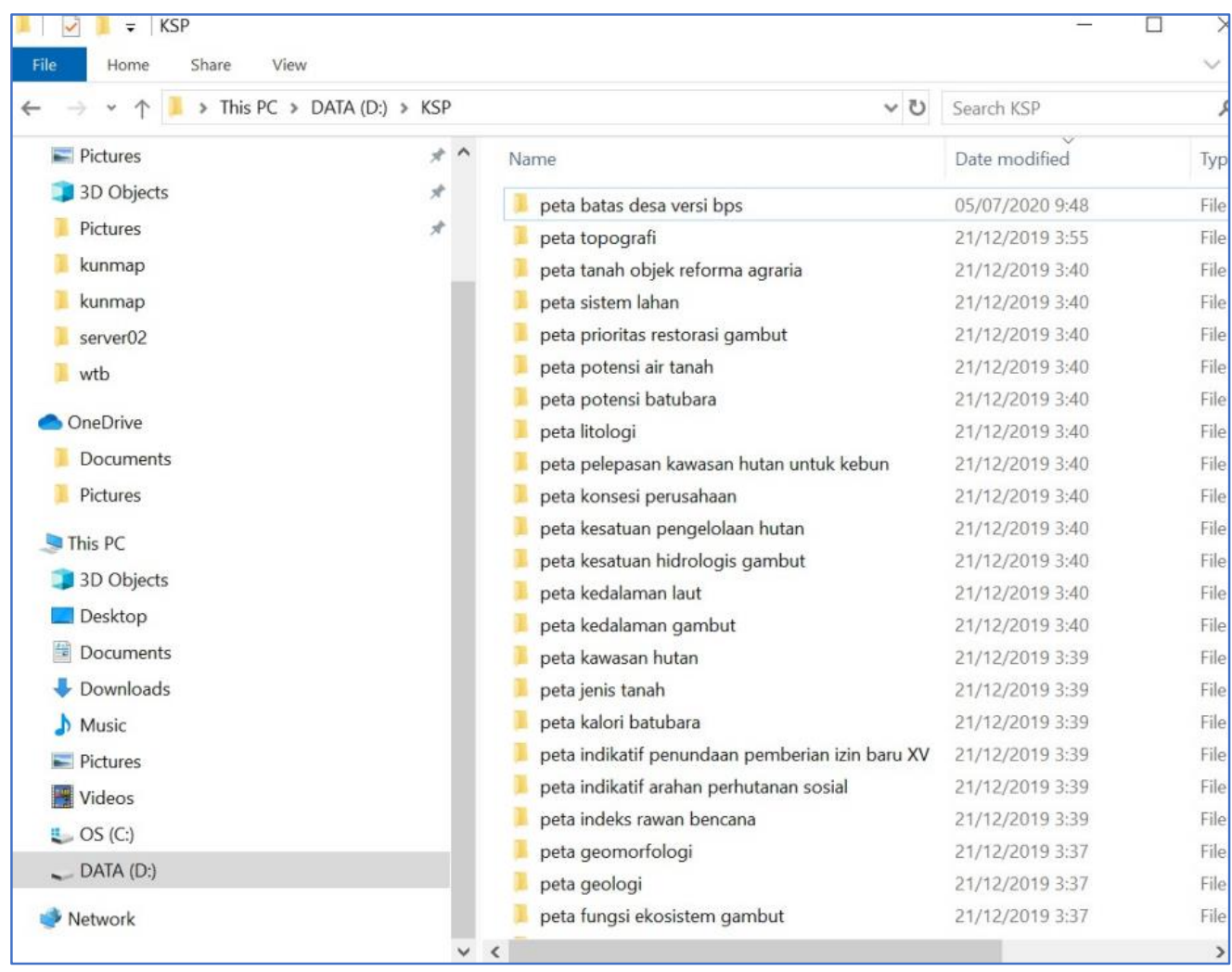

Figure 2. Example results of downloaded data [3] 


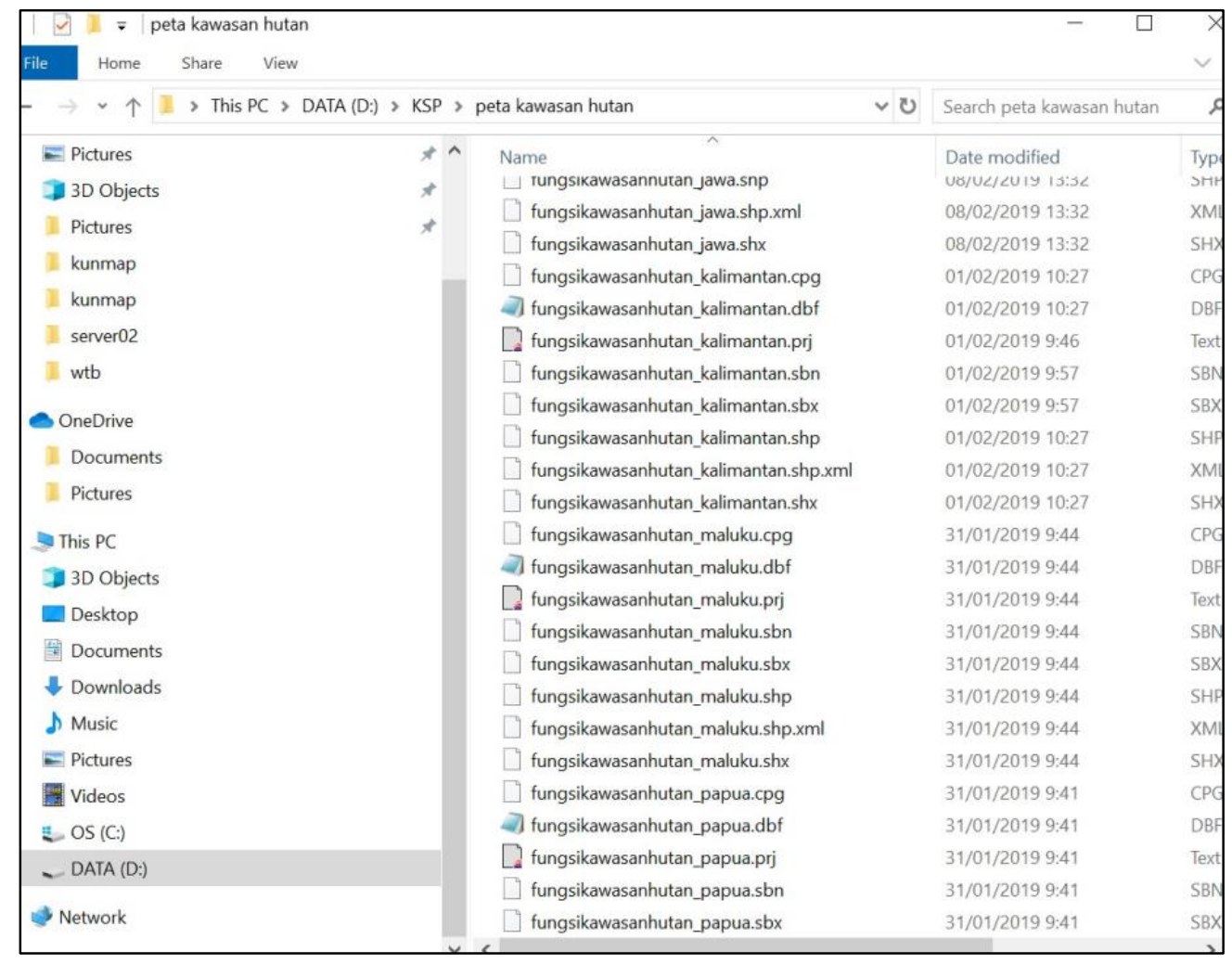

Figure 3. Initial raw data processing [3]

Besides to the suboptimal database, village management so far is still in the form of top-down management. This condition cannot optimize village development so rostoring bottom-up management is highly recommended in the context of accelerating development [4]. This study will demonstrate a web GIS-based village development scheme and application as a solution to the constraints of development assessed from various literatures and policies that have been implemented so far.

\section{METHOD}

This research involved literature study of policy which has been used as a guideline in village development. Furthermore, web GIS optimization and application for pilot villages in a particular sector study based on previous field data acquisition. The acquisition process involves the installation of survey equipment including GPS RTK sets, Ground Control Points (GCP), and Unmanned Aerial Vehicles (UAV) which were previously based on an certain area of interest (AOI). Next orthorectification processing is carried out to compile aerial photography data. The results of orthorectification of aerial photographs are then used for the database and carried out querying data and attributeing it to village cells. The activities in this study are presented in Figure 1. 


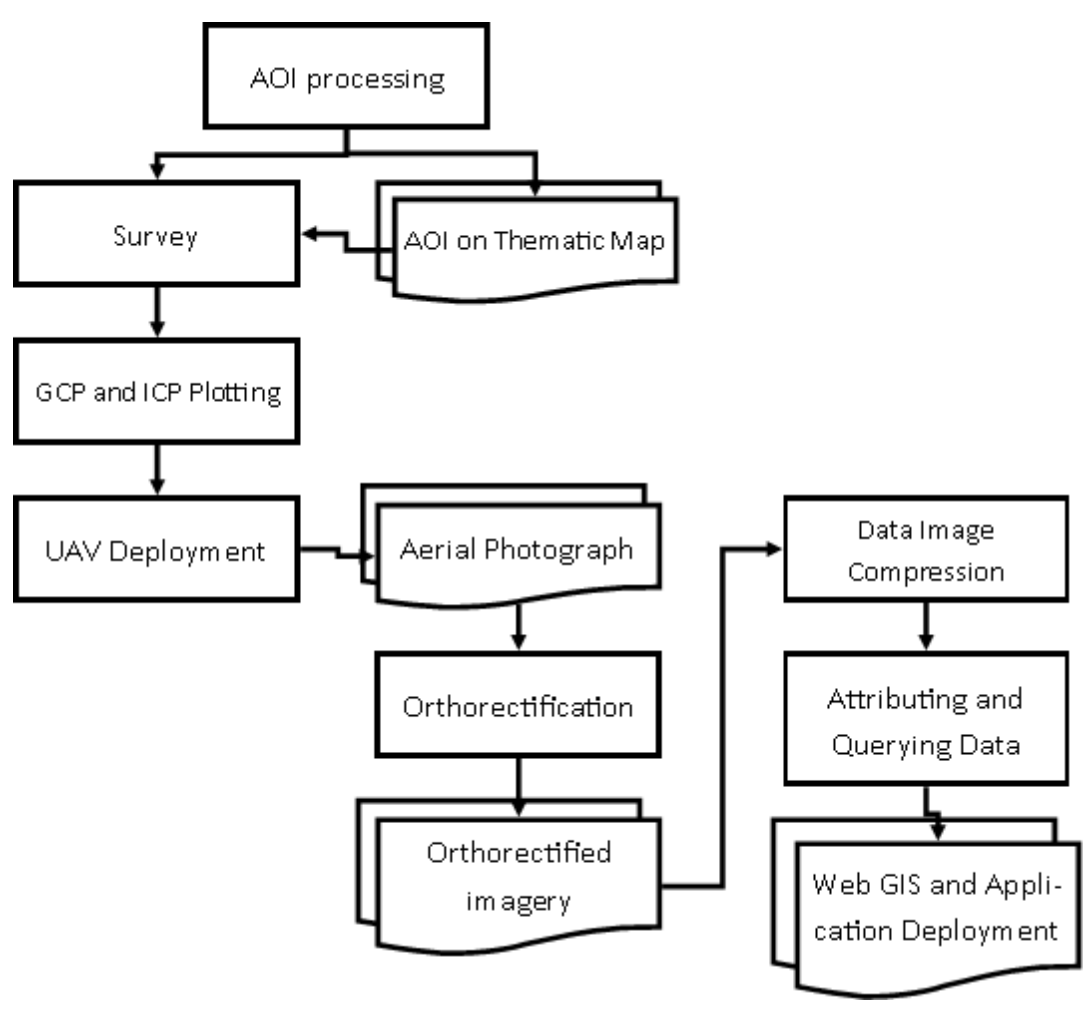

Figure 4. Flowchart study

\section{RESULTS AND DISCUSSION}

Studies conducted on several literatures and policies show that most village development currently tends to use the concept of top-down management. There is still no management concept that makes each individual village as the subject of management, but is more inclined as a managed object. Thus villagers are more often guided by social programs that are also sporadic and incidental. Today, the government needs to encourage citizens to be the subject of management. For example, a plot of land is the smallest cell or unit in a village study.

Updating land area data is an important key in rural area development. Top-down management will not be possible to accommodate when the number of villages in Indonesia reaches more than 86,000 villages. When a village has 1000 plots, that means there will be $86,000,000$ cells that need to be managed. The cell needs to be mapped properly, the village is the one who knows their land better, this is based on the mental map owned by the villagers. Not only mapping activities, data attributing for each cell is also important, and only villagers can optimally do the attributing. Residents of the village community not only know the ability or potential of the village itself, even the capabilities and potential outside the village can be known. With village communities who are able to find out cross-village information, it can also be used for data validation efforts.
Top-down management injustice cases also occur at the village level sometimes. One of them is the case of managing fictious funds which occurred several times in the village. This injustice can be overcome if the village community itself holds the capability and potential data to the smallest cell in the village. As an important note, the villagers mentioned in this study are the whole village communities to the lowest layer. It is not only village officials who are involved as the central government programs that have been implemented for village development. The ability of the villagers to manage the ability and potential of its cells will lead the village to its independence and glory. This is because an independent village is a village that is able to stand alone, but nevertheless can still work together with other villages. Thus the restoration of management from top-down management to bottom-up management needs to be done [4].

This bottom-up management restoration also requires a platform or media that is easy, flexible and up to date, moreover it is free access for the community. Thus the cooperation between parties is needed to develop and assist. On this study we develop the pentahelix approach. This approach is consist of the involvement of academics, government, community, industry and the media. The stakeholdrs involed in this study that described by the pentahelix approach is in line with the Presidential Regulation No. 9/2016 on the Acceleration of One Map Policy [5]. The acceleration mentioned in that regulation requires a masive 
movement from various sectors, and it is reflected by the pentahelix approach brought by this study. The most highlighted variables on the pentahelix approach in this study is media variable. This variable is the thing that need to be given more attention given that in the era of industry 4.0, technology plays an important role for every line of life. The media technology used is renewable, inexpensive and accessible to the public. This proposed recomendation also in line with the Presidential Regulation No. 20/2015 on National Land Agency (BPN) [6]. On this document in poin b, mendtioned formulation of policy implementation in the field of control and handling of disputes and/or land cases. To execute this point, the recomendation proposed by this study can be concluded as the fitest recomendation to be implemented.

In the implementation of bottom-up management restoration combined with pentahelix approaches in media anhancement, one of them is the formulation of a GIS-based village spatial planning and application in Jelobo Village, Klaten Regency (Figure 5). In the initial case of village spatial management, it can be noted that the majority of Jelobo Village residents were 2,276 entrepreneurs. Detailed data is needed to find out the type of business: whether for processing agricultural products or others. The web GIS brought by this study has successfully revealed visually that it turns out to the agricultural/livestock products bussines. It was revealed from the spatial analysis conducted by team and the residents. For the next analysis is how the raw materials of the agricultural/livesotck are supplied, whether fulfilled from within the village or needs to be supplied from outside. If in this case the raw material is not sufficient, is there any land that can be managed to supply the raw material? Then analysis, plans, realization, control, re-analysis, and so on can be made. All stages are recorded and consolidated with web GIS.

In the digital 4.0 era, web GIS does not only produce static map products, but also visualizes land change activities, thematic analysis, plans, realization, monitoring, etc. For other example in Jelobo Village, there are 112 Bachelor and 9 Masters who are able to use the web GIS to create a Business Plan with 50 hectares of available fields. The availability of these fields can be optimized as a cattle feed bank for as many as 500 cattle recorded. Furthermore, we can calculate the results of the sale of grass per month. This can also be used to create a business supply plan for cattle on the feast of sacrifice, assuming an enlargement of cattle for 100 days. Not only the cattle's grass suply but also how to manage the fertizer, and catte's dung: where to get, where to dispose, etc. All these scenarios have been recorded and visualized clearly by using proposed web GIS for the cases in Jelobo Village (Figure 5). It means that by using this web GIS technology in highest precision, real-time, easy, and lightweight, transforming from 15 gigabytes UAV data into less than 3 megabytes data and application, the local government is possible to generate the integrated farming management as well by understanding the availability of each village cells.

Based on the case studies that have been discussed, it can be said that the analysis using web GIS and participatory applications with high accuracy in the village cell will provide more benefits in village management. This product is also in line with the form of management proposed by the $\mathrm{UN}$ in optimizing the implementation of SDG's namely area-based management [7].

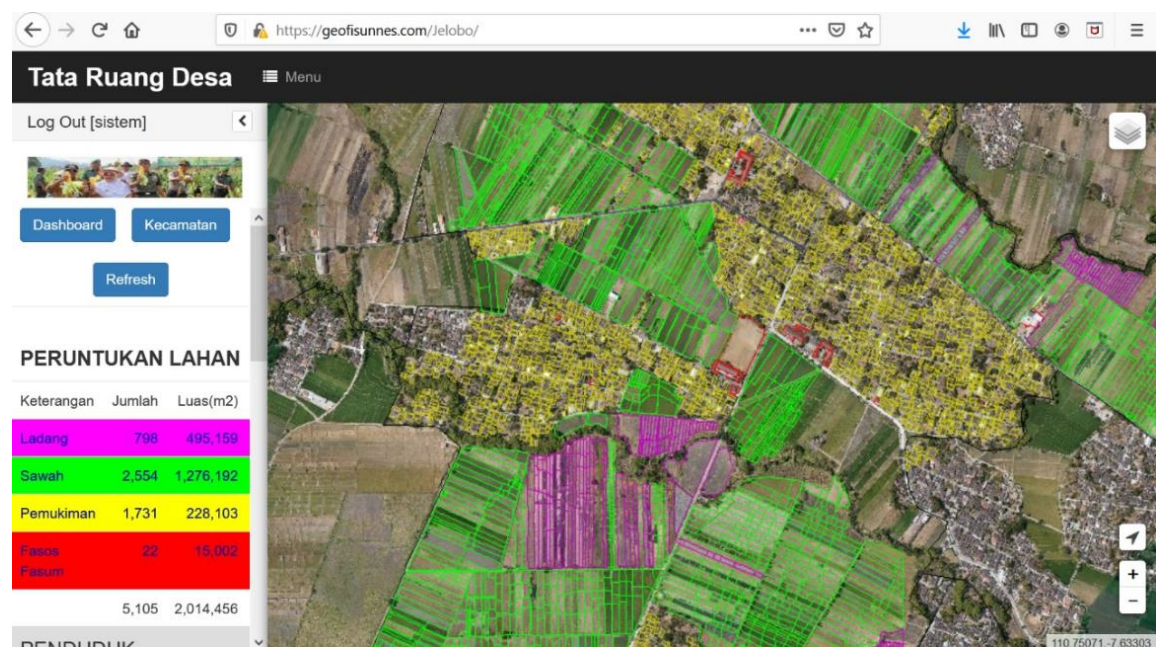

Figure 5. Proposed web GIS Display and application for showing village's cells. 


\section{CONCLUTION}

Bottom-up management is the most suitable management for managing the village. To deal with various problem in this lowest level of the formal government, the managagement should involes pentahelix approach explained in this study. The technology demonstrated in this study is the most upto-date technology in village development efforts. The latest technology can be seen from its ability to handle the availability of detailed scale mapping which has not been optimally available in Indonesia.

\section{ACKNOWLEDGMENTS}

High appreciation and special thanks to the Research and Community Service Institute (LP2M), Universitas Negeri Semarang, for funding this research on the scheme Number 1232/UN37.3.1/PG/2020 entitled Applying the Intelligent and Independent Village Technology Based On Community Participation in Pakintelan Sub-District, Gunungpati District, Semarang City (in Bahasa: Terapan Teknologi Desa Cerdas dan Mandiri Berbasis pada Partisipasi Masyarakat di Kelurahan Pakintelan, Kecamatan Gunungpati, Kota Semarang).

\section{REFERENCES}

[1] Regulation of the Head of Government Goods/Services Procurement Policy No. 22/2015 on the Amendment to the Regulation of the Head of Government Goods/Services Procurement Policy No. 13/2013 on the Guidelines for Procedures for Procurement of Goods/Services in the Village. Official Gazette of the Republic of Indonesia in 2015 Number 1506.

[2] World Bank Group. 2020. Literacy rate, adult total (\% of people ages 15 and above). https://data.worldbank.org/indicator/SE.ADT.LI TR.ZS

[3] BIG. 2020. Geoportal One Map Policy. https://portalksp.ina-sdi.or.id/

[4] Barnes, D. 2002. The Complexities of the Manufacturing Strategy Formation Process in Practice. International Journal of Operations \& Production Management 22, 1090-1111

[5] Republic of Indonesia Presidential Regulation No. 9/2016 on the Acceleration of the Implementation of the One Map Policy at the Accuracy Level of Map Scale of 1: 50,000. Republic of Indonesia State Gazette in 2016 Number 28.

[6] Republic of Indonesia Presidential Regulation No. 20/2015 on National Land Agency (BPN). Republic of Indonesia State Gazette in 2015 Number 21

[7] UN. 2018. The Contributions of Marine and Coastal Area-Based Management Approaches to Sustainable Development Goals and Targets. Technical Report: UN Environment Regional Seas Reports and Studies No. 205. 